\title{
Regional transportation development for development at fertilizer plants in North Sumatra (case study)
}

\author{
Ikhsan Siregar ${ }^{1, *}$, and Mangara M. Tambunan ${ }^{1}$ \\ ${ }^{1}$ Department of Industrial Engineering, Universitas Sumatera Utara, J1. Almamater Kampus USU, \\ Medan 20155
}

\begin{abstract}
Supply chain activity has an opportunity for the occurrence of risk. Therefore, risk management is needed in the handling of risk with the aim to minimize the risk level and impact of those risks. PT. XYZ of PT Pupuk Indonesia (Persero) engaged in the fertilizer industry. The main product produced is urea fertilizer. In the production process, the factory is supported by adequate production facilities and international standard technology. Currently, PT XYZ does not yet have risk management which explicitly discusses the proposed risk management along with the handling strategies required by the company. By looking at the current condition of the company, in order to achieve the goals to be achieved the company needs a good supply chain planning such as by identifying the risks that exist in the supply chain and preventive measures. Performed risk analysis and evaluation of potential supply chain companies using HOR (House Of Risk) tools. After the research there were 42 risk events and 42 risk agents. With the 80/20 pareto approach, 9 risk agents are planned for mitigation action. There are 11 recommended risk mitigation actions recommended to the company in the hope of addressing the risk of urea fertilizer supply chain.
\end{abstract}

\section{Introduction}

A supply chain can be defined as a network which consist of several companies (including suppliers, manufacturers, distributors and retailers) who cooperate and both directly or indirectly engaged in achieveing customer's demands. Supply chain activity has an opportunity for the occurrence of risk. Therefore, risk management is needed in the handling of risk in the aim to minimize the level of risk and risks' impact [1].

PT XYZ is a subsidiary company of PT Pupuk Indonesia (Persero) engaged in the fertilizer industry. The main product is urea fertilizer. In the production process, the factory is supported by adequate production facilities and international standard technology. Vendors are an important part of supply chain management in PT XYZ because all production materials, both auxiliary materials for production, chemical additives to production machines' spare parts are supplied by selected vendors after a tender / auction.

* Corresponding author: ikhsan.siregar@usu.ac.id 
Initial observations showed that there was a delay in the delivery of helping chemicals from 2 days to 106 days. Another problem found in the company is the failure of the bidding process, so that the bidding done repeatedly and resulted the length of the PR process time until the issue of PO and the document confirmation of the specification of the working unit is not available [2-3].

Currently, PT XYZ still does not have any risk management that explicitly discusses the proposed risk management along with the handling strategies required by the company. By looking at the company's condition today, in order to achieve the goals, the company needs a good supply chain planning such as by identifying the risks that exist in the supply chain and preventive measures. Therefore, this research identifies potential risk events occurring in a supply chain, what factors cause the risk to occurs, the relationship between these factors and risks, and how the handling strategy can be used in PT XYZ to handle the risks that usually occur in the supply chain.

In this research will be analyzed and evaluated the risk that potentially appears on the company's supply chain using the HOR (House Of Risk) tools developed by Pujawan and Geraldin. The concept of HOR is similar to the House of Quality (HOQ) concept derived from the Quality Function Deployment (QFD) method. According to Geraldin [4], the HOQ concept will help to design strategies, to identify risks and prioritize risk events that must be addressed first and design a mitigation strategy to reduce or eliminate identified risk agents.

This research is needed for local development. This is necessary for the development of the North Sumatra region, where transportation problems are very influential on product delivery. The company is currently experiencing supply chain problems that affect the timeliness of product acceptance to consumers.

Research on risk mitigation applying the House of Risk (HOR) approach has been conducted and published in a journal entitled "Analysis and Improvement of Risk Management Supply Chain of Rafting Sugar Supply With House Of Risk Approach" and Managing Quality Risk in A Frozen Shrimp Supply Chain: A Case Study [1,9].

\section{Research method}

The research begins with the review and data collection at PT. XYZ. Data obtained through interviews are mapping of company activity based on SCOR model, assessment of severity on risk event, assessment of occurence on risk agent, relationship assessment at risk event with risk agent, mitigation action, assessment of difficulty level on mitigation action and correlation relationship between risk agent with mitigation action [5].

The method used in this study is the approach of House of Risk (HOR) which consists of 2 phases. House of Risk Phase I has the following stages:

1. Identify the risk events that can occur in every business process. Performed through supply chain mapping (plan, source, make, deliver and return).

2. Estimate the impact of some risk events (if they occur) ie Severity ( $\mathrm{Si}$ ).

3. Identify the source of risk and assess the probability of occurrence of each risk source ie Occurence -Oj-.

4. Calculate the relationship of each risk source and each risk event.

5. Calculate the potential aggregate risk group (ARPj) with the formula $A R P j=O j \Sigma$ Si Rij.

6. Rank risk sources based on a collection of potential risks.

While House of Risk Phase II has the following stages:

1. Select multiple risk sources with a high priority ranking that may use pareto analysis from ARPj.

2. Identify consideration of relevant actions for the prevention of sources of risk. 
3. Determine the relationship between each preventive action and each source of riskEjk-.

4. Calculate the total effectiveness of each action as follows TEk $=\Sigma A R P j E j k$.

5. Estimate the degree of difficulty in performing each action.

6. The priority ranking of each action $(\mathrm{Rk})$ in which rank 1 gives the highest meaning of action with ETDk.

\section{Result and discussion}

\subsection{Identification of risk event and risk agent}

Risk identification is a stage to know the risk event that interfere with supply chain activity at company and to know risk agent that cause risk event identification is done through interview at PT. Fertilizer Iskandar Muda. Risk event obtained by mapping of supply chain activity based on SCOR model, then Severity rating for every risk event. The result of risk event identification and assessment can be seen in Table 1 .

The scale used in the severity scores is a scale of 1-10 with the meaning of value 1 (no disturbance effect) and value 10 (risk of causing harmful interference) [6].

Table 1. Risk Event Identification and Assessment

\begin{tabular}{|c|c|c|c|c|}
\hline $\begin{array}{c}\text { Major } \\
\text { Processes }\end{array}$ & Sub-Processes & Risk Event & Code & Sev. \\
\hline \multirow{6}{*}{ Plan } & Demand Forecasting & $\begin{array}{l}\text { Determining the number of } \\
\text { inaccurate requests }\end{array}$ & $\mathrm{E}_{1}$ & 4 \\
\hline & \multirow[t]{5}{*}{ Material Planning } & $\begin{array}{l}\text { The difference between } \\
\text { registered and available stock }\end{array}$ & $\mathrm{E}_{2}$ & 5 \\
\hline & & $\begin{array}{l}\text { Error in writing specification } \\
\text { of the requested item }\end{array}$ & $\mathrm{E}_{3}$ & 7 \\
\hline & & $\begin{array}{l}\text { The requested item is already } \\
\text { obsolete (no longer } \\
\text { production) }\end{array}$ & $\mathrm{E}_{4}$ & 5 \\
\hline & & $\begin{array}{l}\text { Needs of sudden and urgent } \\
\text { goods }\end{array}$ & $\mathrm{E}_{5}$ & 7 \\
\hline & & $\begin{array}{l}\text { Insufficient / accurate media } \\
\text { parameters }\end{array}$ & $\mathrm{E}_{6}$ & 4 \\
\hline \multirow{5}{*}{ Plan } & \multirow[t]{2}{*}{ Production Planning } & $\begin{array}{l}\text { Changes in production plans } \\
\text { are sudden }\end{array}$ & $\mathrm{E}_{7}$ & 3 \\
\hline & & $\begin{array}{l}\text { A sudden machine failure } \\
\text { occurs }\end{array}$ & $\mathrm{E}_{8}$ & 7 \\
\hline & \multirow[t]{2}{*}{ Shipping Planning } & $\begin{array}{l}\text { Mistakes of product delivery } \\
\text { plans }\end{array}$ & $\mathrm{E}_{9}$ & 5 \\
\hline & & $\begin{array}{l}\text { Change of import license of } \\
\text { goods from the government }\end{array}$ & $\mathrm{E}_{10}$ & 5 \\
\hline & $\begin{array}{l}\text { Resource Adjustment with Supply } \\
\text { Chain Requirement }\end{array}$ & $\begin{array}{l}\text { Non-conformity of existing } \\
\text { resources with supply chain } \\
\text { requirements }\end{array}$ & $\mathrm{E}_{11}$ & 7 \\
\hline \multirow{4}{*}{ Source } & \multirow[t]{3}{*}{ Supplier Selection } & $\begin{array}{l}\text { The selection is repeated due } \\
\text { to the failure of the tender }\end{array}$ & $\mathrm{E}_{12}$ & 5 \\
\hline & & $\begin{array}{l}\text { Inappropriate supply partner } \\
\text { supply field }\end{array}$ & $\mathrm{E}_{13}$ & 7 \\
\hline & & $\begin{array}{l}\text { Offering partner prices above } \\
\text { the available budget }\end{array}$ & $\mathrm{E}_{14}$ & 6 \\
\hline & Product Delivery Scheduling from & Delay in goods delivery by & $E_{15}$ & 5 \\
\hline
\end{tabular}




\begin{tabular}{|c|c|c|c|c|}
\hline & Supplier & vendor & & \\
\hline & \multirow[t]{2}{*}{ Product Acceptance } & $\begin{array}{l}\text { Error goods received from } \\
\text { vendor }\end{array}$ & $\mathrm{E}_{16}$ & 6 \\
\hline & & $\begin{array}{l}\text { Incomplete document delivery } \\
\text { of goods from partners }\end{array}$ & $\mathrm{E}_{17}$ & 4 \\
\hline \multirow{3}{*}{ Source } & Quality Checking & $\begin{array}{l}\text { Received goods do not meet } \\
\text { the quality set by the company }\end{array}$ & $\mathrm{E}_{18}$ & 7 \\
\hline & $\begin{array}{l}\text { Provision of Payment Authorities } \\
\text { of Submitted Products }\end{array}$ & $\begin{array}{l}\text { Error authorizing payment of } \\
\text { goods from vendor }\end{array}$ & $\mathrm{E}_{19}$ & 4 \\
\hline & Procurement of goods & $\begin{array}{l}\text { Damage of goods while in the } \\
\text { warehouse }\end{array}$ & $\mathrm{E}_{20}$ & 6 \\
\hline \multirow{9}{*}{ Make } & \multirow[t]{2}{*}{ Production Scheduling } & Delay in production schedule & $E_{21}$ & 4 \\
\hline & & $\begin{array}{l}\text { The occurrence of damage to } \\
\text { machine / mechanical }\end{array}$ & $\mathrm{E}_{22}$ & 7 \\
\hline & \multirow[t]{4}{*}{ Production process } & No production activities & $E_{23}$ & 6 \\
\hline & & $\begin{array}{l}\text { Production is unable to meet } \\
\text { demand }\end{array}$ & $\mathrm{E}_{24}$ & 7 \\
\hline & & $\begin{array}{l}\text { Production activities are } \\
\text { disrupted }\end{array}$ & $\mathrm{E}_{25}$ & 5 \\
\hline & & $\begin{array}{l}\text { The resulting product is not } \\
\text { good / not perfect }\end{array}$ & $\mathrm{E}_{26}$ & 7 \\
\hline & Product Quality Check & $\begin{array}{l}\text { Product quality does not } \\
\text { conform to existing standards }\end{array}$ & $\mathrm{E}_{27}$ & 6 \\
\hline & \multirow[t]{2}{*}{ Packaging Process } & Leakage of product packaging & $\mathrm{E}_{28}$ & 3 \\
\hline & & The packaging is dirty & $\mathrm{E}_{29}$ & 2 \\
\hline \multirow{11}{*}{ Deliver } & Shipping Selection & $\begin{array}{l}\text { The shipping capacity of the } \\
\text { product is less }\end{array}$ & E30 & 3 \\
\hline & & $\begin{array}{l}\text { Incorrect submission of } \\
\text { document submissions }\end{array}$ & E31 & 3 \\
\hline & & Inadequate transportation / less & E32 & 4 \\
\hline & & Lack of transport workers & E33 & 4 \\
\hline & & $\begin{array}{l}\text { The product is damaged while } \\
\text { in the warehouse }\end{array}$ & E34 & 3 \\
\hline & Delivery of goods & Delay of product delivery & E35 & 5 \\
\hline & & $\begin{array}{l}\text { The occurrence of } \\
\text { contamination of goods when } \\
\text { shipping }\end{array}$ & E36 & 2 \\
\hline & Warehousing Activities & Unkempt packaging & E37 & 2 \\
\hline & & $\begin{array}{l}\text { Damage when handling the } \\
\text { product }\end{array}$ & E38 & 2 \\
\hline & $\begin{array}{l}\text { Delivery of goods } \\
\text { Acceptance and Verification of } \\
\text { Goods by Consumer }\end{array}$ & Driver's negligence & E39 & 3 \\
\hline & & Product delivery error & $\mathrm{E} 40$ & 3 \\
\hline Return & $\begin{array}{l}\text { Return of product / defect to } \\
\text { supplier } \\
\text { Return of defective product from } \\
\text { consumer }\end{array}$ & $\begin{array}{l}\text { Late arrival of product / goods } \\
\text { replacement from vendor }\end{array}$ & E41 & 4 \\
\hline & & $\begin{array}{l}\text { Delay return of product / } \\
\text { goods from consumer }\end{array}$ & E42 & 4 \\
\hline
\end{tabular}

Based on Table 1. There were 42 risk events contained in the company's supply chain.

Risk agents are things that can cause a risk event to occur that can disrupt the supply chain activity in the company. Risk agents are obtained from interviews that are then encoded by using letter A which aims to facilitate further readings. Risk assessment agent 
conducted at the time of interview with the PT. XYZ by giving the value of occurence on the assessment form. The result of risk agent identification and assessment can be seen in Table 2 .

Table 2. Identification and Assessment of Risk Agent

\begin{tabular}{|c|c|c|}
\hline Risk Agent & Code & Occurance \\
\hline Forecasting inaccuracies & $\mathrm{A}_{1}$ & 4 \\
\hline Significant increase in consumer demand & $\mathrm{A}_{2}$ & 4 \\
\hline Seasonal factors & $\mathrm{A}_{3}$ & 2 \\
\hline Misinformation and communication & $\mathrm{A}_{4}$ & 2 \\
\hline Lack of coordination & $\mathrm{A}_{5}$ & 2 \\
\hline Error in vendor selection & $\mathrm{A}_{6}$ & 3 \\
\hline The occurrence of trouble / damage suddenly & $\mathrm{A}_{7}$ & 6 \\
\hline Materials interruptions in transit & $A_{8}$ & 2 \\
\hline External factors & $\mathrm{A}_{9}$ & 3 \\
\hline Checking recipient parts of raw materials is not accurate & $\mathrm{A}_{10}$ & 3 \\
\hline The delivery procedure is not organized & $\mathrm{A}_{11}$ & 2 \\
\hline There was an interruption to the raw materials during the trip & $\mathrm{A}_{12}$ & 2 \\
\hline Sets the terms of supplier criteria & $\mathrm{A}_{13}$ & 3 \\
\hline Purchasing SOP & $\mathrm{A}_{14}$ & 1 \\
\hline The purchase list does not include clear specifications & $\mathrm{A}_{15}$ & 7 \\
\hline Efficiency factor during the process & $\mathrm{A}_{16}$ & 4 \\
\hline Unused materials / goods & $\mathrm{A}_{17}$ & 2 \\
\hline Less planning when the process will be done & $\mathrm{A}_{18}$ & 2 \\
\hline Factor reliability of machine tools during the process & $\mathrm{A}_{19}$ & 7 \\
\hline Gas supply is disrupted & $\mathrm{A}_{20}$ & 6 \\
\hline Machine / equipment failure occurred & $\mathrm{A}_{21}$ & 6 \\
\hline Lack of care management & $\mathrm{A}_{22}$ & 6 \\
\hline Package contamination occurs during the storage process & $\mathrm{A}_{23}$ & 3 \\
\hline Power supply is disrupted & $\mathrm{A} 24$ & 2 \\
\hline Internal factors of the company & $\mathrm{A} 25$ & 2 \\
\hline Improper quality checks & $\mathrm{A} 26$ & 2 \\
\hline productionShutdown & $\mathrm{A} 27$ & 7 \\
\hline Sudden material demand & $\mathrm{A} 28$ & 6 \\
\hline Loss / weight reduction / content of the product & A29 & 1 \\
\hline Limited transportation equipment & $\mathrm{A} 30$ & 3 \\
\hline Labor shortage & A31 & 2 \\
\hline Changes to the sales plan & A32 & 2 \\
\hline Less coordination in the warehouse & A33 & 2 \\
\hline Less coordination of shipping parts & $\mathrm{A} 34$ & 2 \\
\hline Natural disasters & $\mathrm{A} 35$ & 1 \\
\hline Interruption during the trip & $\mathrm{A} 36$ & 3 \\
\hline Unsafe transportation by environmental factors & $\mathrm{A} 37$ & 3 \\
\hline Limited warehouse production area & A38 & 2 \\
\hline Lack of communication & A39 & 3 \\
\hline The carrier is damaged & $\mathrm{A} 40$ & 3 \\
\hline Impaired IT system & A41 & 2 \\
\hline The packing of the returned item does not meet the specif & A42 & 3 \\
\hline
\end{tabular}

The scale used in the value of occurence is the scale of 1-10 with the meaning of value 1 (The occurrence of the cause of risk is almost not happening) and the value of 10 (The occurrence of the cause of risk almost always occurs) [6].

Assessment level of risk event relationship with risk agent conducted during interview with PT. XYZ by way of giving relatonship value on the form. The scale used in the 
relationship value is $0,1,3$ or 9 where 0 indicates no relationship, 1 low (low), 3 moderate, and 9 indicates high ties [6].

\subsection{Calculation of Aggregate Risk Potential (ARP)}

ARP calculations are obtained based on the formula:

$$
A R P j=O j \Sigma S i R i j
$$

When:
$A R P j \quad:$ Agregate Risk Potential
Si : Severity
Oj $\quad$ : Occurance
Rij : Relationship

Example calculation ARP1 as follows:

$\begin{array}{lll}\text { Discovered: } & \mathrm{O}_{1}=4 & \\ & \mathrm{R}_{11}=9 & \mathrm{~S}_{1}=4 \\ & \mathrm{R}_{12}=1 & \mathrm{~S}_{2}=5 \\ & \mathrm{R}_{15}=1 & \mathrm{~S}_{5}=7 \\ & \mathrm{R}_{111}=1 & \mathrm{~S}_{11}=7\end{array}$

Asked : $\quad \mathrm{ARP}_{1}$

Answer: $\quad \mathrm{ARP}_{1}=\mathrm{Oj} \Sigma \mathrm{Si} \mathrm{Rij}$

$\mathrm{ARP}_{1}=4 \cdot[9(4)+1(5+7+7)]=220$

Determination of priority risk is performed by looking at the highest ARP value using the 80:20 pareto chart. Pareto diagram of ARP Risk Agent can be seen in Figure 1. From the pareto diagram and the table is then seen the percentage of risk agent has an effect of $80 \%$ of the ARP value for the planned action mitigation. [7]

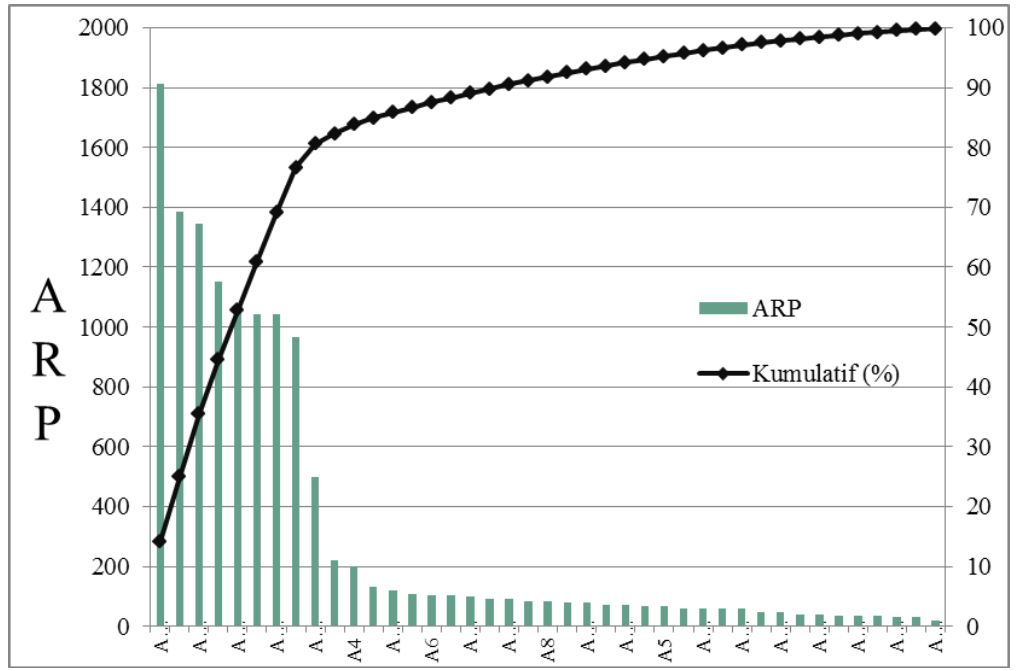

Fig. 1. Aggregate Risk Potential Obtained from Risk Agent Pareto Diagram 


\section{$3.31^{\text {st }}$ Phase house of risk}

House of Risk Phase I is used to determine which risk agents are prioritized for mitigation action. With the $80 \%-20 \%$ pareto approach, $20 \%$ of the risk causes will impact $80 \%$ of potential risk, from Figure 1. above can be seen 9 risk agent of $21 \%$ which gives an impact of $80.58 \%$ against the potential risk, 9 such risk agents:

1. Shut down production (A27).

2. Sudden material demand (A28).

3. Reliability factor of equipment / machine during process (A19).

4. Disturbed gas supply (A20).

5. Lack of care management (A22).

6. The occurrence of trouble / sudden damage (A7).

7. The occurrence of damage to machinery / equipment (A21).

8. The purchase list does not include clear specifications (A15).

9. The power supply is disrupted (A24).

\section{4. $2^{\text {nd }}$ Phase house of risk}

Upon the completion of the HOR of Phase, the second Phase is conducted to produce risk mitigation actions to handle priority risk agents in Phase IHOR. [8-9]

Based on the results of the 9 priority risk agents that will be addressed, 11 risk mitigation actions are made:

1. Provision of adequate spare parts (PA1).

2. Coordination and confirmation of specification of goods / spare parts with the user (PA2).

3. Agreement with PT. Perta Arun Gas on the provision of emergency gas derived from regasifikasi (PA3).

4. Improved coordination between parts (PA4).

5. Schedule and perform preventive maintenance and predictive maintenance (PA5).

6. Turning the Around Factory (per \pm 18 months) (PA6).

7. Substitute equipment / spare parts of factories that have been obsolete (PA7).

8. Improve the performance of production planning and inventory control (PA8).

9. Tighten cooperation, collaboration and information (PA9).

10. Provide power generator / generator set for production purposes (PA10).

11. Coordination with utility unit of power plant (PA11).

In HOR Phase II, Total Effectiveness is calculated. Total effectiveness can be calculated based on the formula:

$$
T E_{k}=\Sigma A R P_{j} E_{j k}
$$

Explanation:

$T E \quad$ : Total Effectiveness

$A R P$ : Agregate RiskPotential

E :Effectiveness

Example calculations for TE1 are as follows:

Discovered: $\quad \mathrm{ARP}_{27}=1813 ; \mathrm{ARP}_{7}=1044 ; \mathrm{ARP}_{21}=1044$

$$
\begin{aligned}
& \mathrm{E}_{127}=3 \\
& \mathrm{E}_{121}=3
\end{aligned} \quad \mathrm{E}_{17}=3
$$


Asked : $\quad \mathrm{TE}_{1}$

Answer: $\quad \mathrm{TE}_{\mathrm{k}}=\Sigma \mathrm{ARP}_{\mathrm{j}} \mathrm{E}_{\mathrm{jk}}$

$$
\mathrm{TE}_{1}=[(1813 \cdot 3)+(1044 \cdot 3)+(1044 \cdot 3)]=11703
$$

Furthermore, TEk calculation is entered into House of Risk Phase II. The value of Effectiveness (level of relationship between mitigation and risk agent) is $0,1,3$ or 9 where 0 indicates the absence of linkage, 1 low (low), 3 moderate, and 9 indicates high ties [4].

After the calculation of TEk then calculate the Effectiveness to Difficulty Ratio which can be calculated by using the formula:

$$
E T D k=\frac{\mathrm{TE}_{\mathrm{k}}}{\mathrm{D}_{\mathrm{k}}}
$$

While:
ETD : Effectiveness to Difficulty Ratio
TE : Total Effectiveness
$D \quad$ : Difficulty

Example calculations for ETD1 are as follows:

Discovered: $\quad \mathrm{TE}_{1}=11703$

$$
\mathrm{D}_{1}=5
$$

Asked :

$$
\mathrm{ETD}_{1}
$$

Answer:

$$
\begin{aligned}
\text { ETDk } & =\frac{T E_{k}}{D_{k}} \\
\text { ETDk } & =\frac{11703}{5}=2340,6
\end{aligned}
$$

The scale used in the Difficulty score is a value of 3, 4, 5 with the meaning of value 3 indicating low difficulty, moderate 4 and 5 showing high difficulty [4]. Assessments and calculations on risk mitigation actions are incorporated into Phase II HOR as in Table 3.

Tabel 3. $2^{\text {nd }}$ Phase of House of Risk

\begin{tabular}{|c|c|c|c|c|c|c|c|c|c|c|c|c|}
\hline \multirow{2}{*}{$\begin{array}{c}\text { Risk } \\
\text { Agent }\end{array}$} & \multicolumn{8}{|c|}{ Risk Mitigation Action } & \multirow{2}{*}{ ARP } \\
\cline { 2 - 14 } & $\mathbf{P A}_{\mathbf{1}}$ & $\mathbf{P A}_{\mathbf{2}}$ & $\mathbf{P A}_{\mathbf{3}}$ & $\mathbf{P A}_{\mathbf{4}}$ & $\mathbf{P A}_{\mathbf{5}}$ & $\mathbf{P A}_{\mathbf{6}}$ & $\mathbf{P A}_{\mathbf{7}}$ & $\mathbf{P A}_{\mathbf{8}}$ & $\mathbf{P A}_{\mathbf{9}}$ & $\mathbf{P A}_{\mathbf{1 0}}$ & $\mathbf{P A}_{\mathbf{1 1}}$ & \\
\hline $\mathbf{A}_{\mathbf{2 7}}$ & 3 & & 9 & & 9 & 3 & & & & 3 & & 1056 \\
\hline $\mathbf{A}_{\mathbf{2 8}}$ & & & & & & & & 9 & 1 & & & 917 \\
\hline $\mathbf{A}_{\mathbf{1 9}}$ & & & & & 9 & 9 & 1 & & & & & 750 \\
\hline $\mathbf{A}_{\mathbf{2 0}}$ & & & 9 & & & & & & 3 & & & 624 \\
\hline $\mathbf{A}_{\mathbf{2 2}}$ & & & & 1 & 9 & 9 & & & 3 & & & 585 \\
\hline $\mathbf{A}_{\mathbf{7}}$ & 3 & & & & 9 & 3 & & & & & & 510 \\
\hline $\mathbf{A}_{\mathbf{2 1}}$ & 3 & & & & 3 & 3 & 3 & & & & & 420 \\
\hline $\mathbf{A}_{\mathbf{1 5}}$ & & 9 & & 3 & & & & & 3 & & & 329 \\
\hline $\mathbf{A}_{\mathbf{2 4}}$ & & & & & & & & & & 9 & 9 & 312 \\
\hline
\end{tabular}

Tabel 4. $2^{\text {nd }}$ phase of House of Risk

\begin{tabular}{|c|c|c|c|c|c|c|c|c|c|c|c|}
\hline \multirow{2}{*}{ Risk Agent } & \multicolumn{10}{|c|}{ Risk Mitigation Action } \\
\cline { 2 - 13 } & PA $_{1}$ & PA $_{\mathbf{2}}$ & PA $_{3}$ & PA $_{4}$ & PA $_{5}$ & PA $_{6}$ & PA $_{7}$ & PA $_{8}$ & PA $_{9}$ & PA $_{10}$ & PA $_{11}$ \\
\hline TE & $\mathbf{1 1 7 0 3}$ & $\mathbf{8 6 9 4}$ & $\mathbf{2 6 6 8 5}$ & $\mathbf{3 9 6 0}$ & $\mathbf{5 0 4 9 9}$ & $\mathbf{3 3 3 5 7}$ & $\mathbf{4 4 7 6}$ & $\mathbf{1 2 4 7 4}$ & $\mathbf{1 0 9 2 6}$ & $\mathbf{9 9 2 1}$ & $\mathbf{4 4 8 2}$ \\
\hline D & $\mathbf{5}$ & $\mathbf{3}$ & $\mathbf{5}$ & $\mathbf{3}$ & $\mathbf{4}$ & $\mathbf{5}$ & $\mathbf{3}$ & $\mathbf{3}$ & $\mathbf{3}$ & $\mathbf{5}$ & $\mathbf{3}$ \\
\hline ETD & $\mathbf{2 3 4 0 , 6}$ & $\mathbf{2 8 9 8 , 0}$ & $\mathbf{5 3 3 7 , 0}$ & $\mathbf{1 3 2 0 , 0}$ & $\mathbf{1 2 6 2 4 , 8}$ & $\mathbf{6 6 7 1 , 4}$ & $\mathbf{1 4 9 2 , 0}$ & $\mathbf{4 1 5 8 , 0}$ & $\mathbf{3 6 4 2 , 0}$ & $\mathbf{1 9 8 4 , 2}$ & $\mathbf{1 4 9 4 , 0}$ \\
\hline Rank & $\mathbf{7}$ & $\mathbf{6}$ & $\mathbf{3}$ & $\mathbf{1 1}$ & $\mathbf{1}$ & $\mathbf{2}$ & $\mathbf{1 0}$ & $\mathbf{4}$ & $\mathbf{5}$ & $\mathbf{8}$ & $\mathbf{9}$ \\
\hline
\end{tabular}




\section{Conclusion}

The conclusion that can be obtained after finished the data processing and problem-solving analysis on Supply Chain Risk and Supply Mitigation at PT. XYZ with House of Risk Approach (HOR) is as follows:

1. Identification of risks that contained in the supply chain activities of PT. XYZ generates 42 risk events and 42 risk agents

2. First Phase of House of Risk produces 9 risk agents of $21 \%$ which gives an impact of $80.58 \%$ on potential risks based on pareto diagram ie shutdown of production (1813), sudden material demand (1386), reliability factor of equipment / machine during process (1044), the occurrence of trouble / damage (1044), the occurrence of damage to machinery / equipment (1044), the purchase list does not include clear specifications (966), the supply of electricity disturbed (498).

3. Obtained 11 supply chain mitigation plans of PT. XYZ

4. House of Risk Phase II produces risk mitigation action recommended to PT. Iskandar Muda Fertilizer in mitigating risks to the company's supply chain activities. The Company can perform risk mitigation actions starting from the action with the highest Effectiveness to Difficulty Ratio value that is scheduling and doing preventive maintenance and predictive maintenance (12624.8), Turn Around factory (per \pm 18 months) $(6671,4)$, agreement with PT. Perta Arun Gas on the provision of emergency gas derived from regasification (5337), improving the performance of production planning and inventory control (4158), strengthening cooperation, collaboration and information (3642), coordination and confirmation of specifications of factory / spare parts with user (2898), provision of adequate spare parts (2340.6), providing power generators / generator sets for production purposes $(1984,2)$, coordinating with utility generating units 1494, substituting obsolete plant equipment (1492) coordination between sections (1320).

\section{References}

1. D. Anggrahini, Dkk. Industrial Engineering And Service Science 2015. Elsevier.B.V. (2015)

2. I. Fahmi, Manajemen Risiko. Bandung: Alfabeta (2010)

3. M. Hanafi, Manajemen Risiko. Yogyakarta: UPP STIM. (2006)

4. Pujawan, I Nyoman Dan Laudine H. Geraldine., Business Process Management Journal, 15, 6, pp. 953-967, (2009)

5. Pujawan, I Nyoman. Supply Chain Management. Surabaya: Guna Widya (2005)

6. A. Shahin, International Journal Of Quality \& Reliability Management, 21, 7, pp. 731746, (2004)

7. S. Sinulingga, Metode Penelitian. Edisi Ketiga. Medan: USU Press. (2015)

8. Supply Chain Council. Supply Chain Reference Model. Overview Version 10.0. (2010)

9. M. Ulfah, Dkk. Jurnal Teknologi Industri Pertanian. Bogor: Institut Pertanian Bogor (2016) 